Citation: İşeri Uzunoğlu, M. \& Sözer, E.G., Cognitive, Perceptual And Behavioral Effects Of Neuro-Stimuli: A Study On Packaged Food Products, BMIJ, (2020), 8(3): 3097-3122, doi: http://dx.doi.org/10.15295/bmij.v8i3.1513

\title{
COGNITIVE, PERCEPTUAL AND BEHAVIORAL EFFECTS OF NEURO-STIMULI: A STUDY ON PACKAGED FOOD PRODUCTS
}

\author{
Merve İşERI UZUNOĞLU 1 \\ Edin Güçlü SÖZER 2
}

\author{
Received Date (Başvuru Tarihi): \\ Accepted Date (Kabul Tarihi): \\ Published Date (Yayın Tarihi):
}

$20 / 05 / 2020$

$28 / 06 / 2020$

$25 / 09 / 2020$

In the article, the first author is in the role of the Corresponding Author.

\begin{abstract}
Today, the food sector is characterised with intense competition and continuously becoming more challenging for marketers. When it is realised that $95 \%$ of consumers' purchasing decisions are Keywords:

Neuro-stimulus, made unconsciously, marketing tools started to target unconscious minds. Combining neuroscience and marketing disciplines, neuromarketing studies found that neuro-stimuli, directly addressing the brain, are influential on consumer perceptions. This study investigates

Neuromarketing,

Brand Awareness, the effects of neuro-stimuli applied on food product poster and packaging on mother-woman and child consumers' brand awareness, quality perceptions and purchase intentions. In the experimental design implemented, a total of 284 subjects composed of women and children are Perceived Quality,

Purchase Intention divided into 6 groups, and they were exposed to various degrees of neuro-stimuli in the poster and product packages in order to measure the influence of these stimuli. Findings of the research confirmed that application of neuro-stimuli significantly increased quality perception of women

JEL Codes:

M310 and purchase intentions of both woman and child consumers. Increasing intensity of neurostimuli also generated a partially significant influence. Theoretical and managerial implications are provided based on these findings.
\end{abstract}

\section{NÖRO-UYARANLARIN BİLISŞSEL, ALGISAL VE DAVRANIŞSAL ETKİLERİ: AMBALAJLI GIDA ÜRÜNLERI ÜZERİNE BİR ÇALIŞMA}

\section{$\ddot{O Z Z}$}

Anahtar Kelimeler:

Nöro-Uyaran,

Nöropazarlama,

Marka Farkındalığı,

Kalite Algisl,

Satmalma Niyeti

JEL Kodları:

M310
Günümüzde gıda sektörü yoğun rekabet düzeyi ile özdeşleşmiş ve pazarlamacılar açısından oldukça zorlayıcı şartlar oluşturmaya başlamıştır. Tüketicilerin satın alma işlemlerinin \% 95'ini bilinçsiz bir şekilde gerçekleştirdikleri fark edildiğinde, pazarlama araçları da bilinç dı̧̧ı beyni hedeflemeye başlamıştır. Nörobilim ve pazarlama disiplinlerini bir araya getiren nöropazarlama çalışmaları, direkt olarak beyini hedefleyen nöro-uyaranlarm tüketici algılarn üzerinde etkili olduğunu göstermektedir. Bu çalı̧̧a, poster ve ürün ambalajı üzerinde uygulanan nörouyaranların anne-kadın ve çocuk tüketicilerin marka farkındalı̆̆l, kalite algısı ve satın alma niyeti üzerindeki etkilerini incelemektedir. Kurgulanan deneysel tasarm kapsaminda kadin ve çocuklardan oluşan 284 katılımo 6 gruba ayrılmış ve poster ve ambalajlar üzerinde uygulanan farkh nöro-uyaran yoğunluk seviyelerine maruz kalmışlardır. Araştırma sonuçları nöro-uyaran uygulamalarının kadın tüketicilerin kalite algılarında, yine kadın ve çocuk tüketicilerin ise satın alma niyetlerinde pozitif yönde etkiye neden olduğunu göstermektedir. Buna ek olarak, uygulanan nöro-uyaran yoğunluğu artıs gösterdikçe, kısmi olarak anlaml bir pozitifetkiye neden olmaktadır. Çalısmanın bulguları kapsamında akademik ve uygulamaya yönelik değerlendirmeler sunulmuştur.

\footnotetext{
${ }^{1}$ Altınbaş University, merve.iseri@altinbas.edu.tr,

2 Asst. Prof., Okan University, edin.sozer@okan.edu.tr,
} 


\section{INTRODUCTION}

The new dynamics of the global market resulted in intense competition among food products, and the competition necessitates effective marketing communication for marketers to differentiate their products. When we consider child-oriented packaged food products, target segments are children and mothers for marketing activities. Whatever is the target segment of the brand, consumer preferences are directly influenced by brand awareness, brand value and buying experience (Kotler et al. 2017). Thus, effective marketing communication is a fundamental element to increase brand awareness and build quality perception (Topçu et al. 2007). Designing effective marketing communications requires the identification of effects generated by marketing stimuli on consumer perceptions, emotions, and behaviour. In order to have a better understanding of such stimuli on consumer behaviour, marketing sector collaborated with neuroscience and focused on consumer's brain.

In 1954, Olds and Milner discovered the functional neuroanatomy of pleasure in the brain, which enabled marketers to find a way to establish a permanent emotional relationship with the consumers (Kringelbach \& Berridge, 2010). Today, it is known that ventral striatum region of the brain executes award evaluation and shapes individuals' behaviours and preferences (Yorganc1lar, 2015). Hence, marketers, today focus more on a subconscious or neural stimuli rather than conscious due to proven results of studies evoking that brain's tendency is towards alternatives coded as an award. Neuroscience and marketing started to collaborate with the studies of Gerald Zaltman, a Harvard professor, which led to the rise of the new sub-discipline for marketing called neuromarketing (Kumar \& Singh, 2015). Neuromarketing is defined as the application of neuroscience techniques on consumers to understand their behaviour and to measure their response to marketing stimuli (Singh, 2015).

Fast Moving Consumer Goods (FMCG) food sector appeals to five senses and involves intense competition so that this sector pioneered the application of neuromarketing techniques to benefit from revealing subconscious and to understand the emotional reactions. Although Maslow located food at the base of the Hierarchy of Needs pyramid as a basic physiological need, food transformed into a tool of 
communication involving various meanings in social life. Food appeals to five senses and triggers a wide array of neural transmitters in the brain. Therefore, neuroscience can be utilised to reveal the black box of the consumer and understand the target consumer group. This study targets to measure the effects of neuromarketing techniques, which are applied in marketing mix elements for food products, on the behaviours of mother-women and children consumers. The study focuses on the effect of such techniques on brand awareness, quality perception and intention to purchase dimensions of consumer behaviour. The subject and experimental design of this study, as well as the data collected, are based on a Master's thesis written and completed by Uzunoğlu (2019) for the graduation from a Gastronomy Program in a private university in Istanbul.

\section{LITERATURE REVIEW}

\subsection{Neuromarketing and Consumer Behavior}

Because consumers are emotional creatures, it can be stated that all purchase decisions are made in the 'black box' (mind) of the consumers that require comprehensive analysis to understand the decision-making process. In most cases, the exact definitions fail without understanding the way the brain functions when exposed to a stimulus. Neuromarketing is a multi-disciplinary area that enables observation and measurement of the controlled and uncontrolled processes in the brain. The main objective is to explain the neurological process of purchase decision (Yorganc1lar, 2015). Also known as consumer neuroscience, neuromarketing is a research model benefiting from fields such as neuroscience, psychology, neurology, and physiology. The techniques require the utilisation of technology, medical knowledge, and marketing techniques (Ustaahmetoğlu, 2015). Neuromarketing focuses on subconscious rather than conscious because according to previous studies, consumer behaviour and consumers' cognitive responses are inconsistent (Renvoise \& Morin, 2017). Brain imaging and body response measurement techniques used in neuromarketing aim to measure consumer reactions to product/service, packaging, advertisement, or an emotional marketing method. 
Neuromarketing technique is based on information units stored in the brain called 'meme', which are influential on decisions made in 2.6 seconds (Kumar \& Singh, 2015). Marketers try to create useful memes that stay in memory to affect future purchase decisions because the limbic system is the egocentric part of the brain that mainly focuses on survival. It is a mechanism that functions fast and minimises risks that are activated by emotions (Renvoise \& Morin, 2017). Award centres called nucleus accumbent in the ventral striatum area of the limbic system enable us to respond to external stimuli (Dalenberg et al., 2017) Neuromarketing aims to motivate limbic system to direct the consumers to the desired behaviour. Neuroscientific methods are applied to obtain objective consumer responses from their body language eliminating inconsistency of verbal responses (Calvert \& Brammer, 2012)

\subsection{Neuromarketing and Application Areas}

Multi-disciplinary nature of neuromarketing enables a wide range of marketing application methods such as advertisement efficiency, brand loyalty, the effect of the brand logo, product development and pricing (Yücel \& Coşkun, 2018). Advertisement efficiency is measured by activation of the medial prefrontal cortex ( $\mathrm{MPFC}$ ) that is in frontal brain lobe associated with abstract thinking, planning, reasoning and personal assessment (Kömürcüoğlu, 2016). For instance, Bozoklu and Alkibay (2014) revealed that Electromyography is more effective than a survey to measure advertisement effectiveness. The trust of the consumer can measure brand loyalty to a brand, which is an emotional component measured using neuroscientific methods (Yücel \& Coşkun, 2018). Similarly, exposure to a brand logo increases oxygenated blood flow in mPFC that can be measured by utilising fMRI imaging (Kömürcüoğlu, 2016). In a coffee tasting study by Yücel et al. (2015), EEG method is used to reveal that consumers cannot differentiate and select their preferred coffee brand by taste, but only by brand name. More importantly, in the product development stage designing the most effective and unique packaging has become prerequisite for a consumer purchase decision. Neuromarketing methods are utilised for effective designs by measuring the interaction between packaging and consumer (Ceylan \& Ceylan, 2015) Consumers have psychological limits that they are willing to pay for a particular product depending on benefits of the brand on consumer's emotional satisfaction. 
Neuroscientific methods help to comprehend the optimal price for the product (Yücel \& Coşkun, 2018). According to Ustaahmetoğlu (2015), all neuroscientific methods need to be supported by traditional data collection methods to obtain precise results.

\subsection{Fundamental Stimuli and Effects on Consumer Behavior}

Consumer behaviour is defined as all behavioural actions displayed by the consumer for searching, purchasing, using, evaluating, and disposing of products, services, and ideas (Schiffman \& Kanuk, 1997). The definition mentioned above has broadened as the consumer's decision on how to utilise possessed resources such as time, money, and effort (Durmaz et al., 2011). Consumer purchasing behaviours are affected by many direct or indirect, internal, or external factors. Rational consumer decision processes are analysed by various models that in a common aim to explain consumer choices utilising empirical methods. The 1960s was the beginning of analysing consumer behaviour from a marketer's perspective (Howard and Sheth, 1969). According to the authors, the common point of all consumer behaviour models is to create consumer loyalty, behavioural intention, and planning sales plans. Each model accepts the cognitive differences and biases caused by consumer background and considers personality traits and effects of the environment on purchasing decisions.

One of these environmental factors, which is expected to shape consumer behaviour, consists of external stimuli that consumer perceives with five senses. Neuroscience is utilised to measure consumers' level of responsiveness to such stimuli (Yorgancilar, 2015). Mostly food product choices are made through a combination of all five senses (Auvray \& Spence, 2008). Although food products are associated with mostly taste, packaged food products are bought by utilising all senses but tasting. The dilemma mentioned above is resolved by our brain using a matching technique. The brain records all previous experiences to define approaches to new products (Cosmi, Scaglioni \& Agostoni, 2017).

In the retail market, consumers are first exposed to a visual stimulant of a food product. Such a stimulus can be either the product itself or its packaging, advertisement, or visual representation. Oxford University experimental psychology 
professor Charles Spence (2016) specifies in several of his studies that visual sense is primary for choosing packaged food products. It does not require physical contact and is effective from a distance, so first data about the product is sent to the brain via visual sense. Hence, first bias and intention are generated based on visual data. Among all visual stimuli, the most predominant sensory stimuli are colours that affect consumer perception (Spence, 2015). According to the results of various studies, 62 to $90 \%$ of consumers influenced by colours at purchasing decisions (Spence \& Velasco, 2018). Colours create psychological product expectation (Spence, 2015). For instance, more intensity in product colour indicates a higher intensity in taste for adult consumer brain and shapes consumer experience. In marketing, bright and vivid coloured packaging is children-oriented, whereas soft, opaque, and low-intensity colours aim at older adults (Spence \& Velasco, 2018). Similarly, such soft colours connote lower salt, sugar and fat levels in the product, creating a perception of the healthier product (Lindstrom, 2009).

Shapes and angles are also considered to be influential on consumer perceptions. In their study, Spence \& Ngo (2017), reported that shapes and angles affect consumer taste perceptions. Such studies guided marketers to utilise shape symbolism in the food sector in packaging design, logo, and similar marketing stimuli. Soft angles, round and oval shapes evoke sweet tastes whereas sharp edges more bitter tastes. Similarly, sharp-cornered star, triangular shapes are associated with gaseous (fizzy) products that are strong. The olfactory sense is related to taste sense. Both orthos nasal and retronasal olfaction is activated during food consumption and send message to the brain via olfactory epithelium (Yin et al. 2017). Orthonasal transmission aids defining pre-experienced food products and create award expectation (Yin et al. 2017). Stevenson, Prescott and Boakes (1999) found that smell can fortify or suppress tastes, effecting food experience directly. Haptic and tactile senses are the first developed senses in the womb, and our skin full of haptic receptors covers $16-18 \%$ of the body (Spence, 2017). Importance of tactile sense is disregarded for so long, but recent neuroscientific studies revealed the significance of tactile stimuli on consumer preferences. According to Gallace and Spence, product packaging creates expectations about intrinsic product properties (Spence, 2017). Congruence between the product 
and the form, texture of packaging design creates an association in consumer mind and direct consumer preferences.

\subsection{Neuro-Stimuli and Effects on Consumer Behavior}

Neuro-stimulus is the type of stimulus that leads to hormonal secretion in egocentric and emotional brain and activate certain regions affecting consumer behaviour subconsciously. According to Zaltman, who is considered as the father of neuromarketing, 95\% of consumer emotions, thoughts, and experiences are subconscious. The prefrontal cortex is responsible for final decision making, yet marketing activities targeting prefrontal cortex and ignoring emotional brain are expected to fail (Dooley, 2012). Neuro-stimuli, which are related to human senses, are considered as external stimuli that trigger unconscious brain activities and stimulate the limbic system severely. Studies regarding neuro-stimuli investigate the stimuli activating specific regions of the brain to develop a measuring technique. Literature still lacks a common technique but full of independent studies. The brain is neuroplastic (Dooley, 2012); it is an amorphous and ever-changing organ. Thus, only brands that can cause permanent changes in the brain can succeed.

Consumer choices are a combination of conscious and subconscious processes, yet subconscious processes are the core factors. Individuals perceive most external stimuli subconsciously (Fitzsimons et al. 2002). Consumers are exposed to stimuli on products very frequently; however, they focus only on certain stimuli consciously (Smith \& DeCoster, 2000). In marketing strategy design, most product information is not available to the conscious mind but still can be directly useful in decision processes (Friese et al. 2006). Consumer awareness is raised by exposing to marketing tools, reflecting product before being exposed to the product itself. In line with the existing literature and findings of the studies, the following hypothesis is proposed:

$\boldsymbol{H}_{1}$ : Effective application of neuro-stimuli on marketing mix elements will lead to an increasing level of brand awareness level of consumers.

Consumer brand awareness is a crucial factor for products of brands competing in the fast-moving consumer goods sector involving intense level of competition. Marketing tools generate quality perception before purchase and through product 
experiences generated as a result of an alliance of intrinsic and extrinsic stimuli (Hansen, 2005). Intrinsic cues are related to physical properties of the product, whereas extrinsic cues are related to the brand, price, and packaging design, not related to product characteristics but perception changing stimuli. Coherence in product features and consumer expectations reinforce the quality perception. For instance, light pink colour is associated with sweet tastes like strawberry (Spence, 2017). Hence, colours in marketing communication should be associated with the food product itself for perception management: quality perception affects consumer experience and brand judgement directly (Anselmsson et al. 2007). Additionally, in the context of lowinvolvement products, purchase intention is formed mainly by visual marketing communication (Silayoi \& Speece, 2004). In line with the existing literature and findings of the studies, the following hypotheses are proposed:

$\boldsymbol{H}_{2}$ : Effective application of neuro-stimuli on marketing mix elements, will lead to increasing levels of brand quality perception of consumers.

$\mathrm{H}_{3}$ : Effective application of neuro-stimuli on marketing mix elements will lead to increasing levels of purchase intention of consumers.

Consumers make instantaneous purchase decisions when buying fast-moving consumer goods. According to Rundh (2007), a shopper in a supermarket is exposed to 300 brands per minute. Accordingly, a product has one-tenth of a second to grab consumer's attention and encourage purchase intention. The most effective method to grab consumer's attention at an instant is to use the appropriate colour, size, communication and visual aspects for brand and product (Schlossberg, 2008). Packaging design is a strategic tool for differentiation and brand value creation (Vazquez et al. 2003). Thalhammer (2007) argues that product packaging is a subliminal communication method for producers with consumers so that consumers make an evaluation and differentiate brand identity from others (Chung et al. 2006). Intensive competition in the food sector caused brands to put more importance on their packaging designs (Wang, 2013). Hence, it is strongly believed that the utilisation of neuro-stimuli both on visual communication tools and packaging, will enhance 
brand awareness. In line with the existing literature and findings of the studies, the following hypothesis is proposed:

$\mathbf{H}_{4}$ : Increasing intensity of neuro-stimuli application on marketing mix elements will lead to an increasing level of brand awareness of consumers.

According to Silayoi and Speece (2004), visual packaging features generate brand awareness as well as shape product expectations even though the consumer does not possess previous knowledge about a product and its specifications. Consumers form product benefit expectations by visual stimuli (Wang, 2013). For food products, it is impossible to determine product quality before purchase; therefore, visual references are perceived as quality indicators (Venter et al. 2011). Product quality perception is related to the positioning of the product. Functional and visual packaging, designed according to product positioning, defines consumer's product quality perception (Ampuero \& Vila, 2006). In line with the existing literature and findings of the studies, the following hypothesis is proposed:

$\mathbf{H}_{5}$ : Increasing intensity of neuro-stimuli application on marketing mix elements will lead to an increasing level of quality perception of consumers.

According to Jugger (2008), last five seconds before purchasing is critical for the transformation of purchase intention into action. The consumer is directly exposed to and in touch with packaging in those last seconds, leading to a conclusion that packaging has a critical role in purchase intention. Moreira, Fortes and Santiago (2017) conducted a study with 302 consumers and revealed that multi-sensorial stimuli have a direct positive effect on product experience, brand value perception and purchase intention. Parallel to the findings in the marketing literature, it is strongly believed that combining soft angles in the visual design of packaging will shape to evoke sweet tastes, which will eventually lead to increased purchase intentions (Spence \& Ngo, 2017). In line with the existing literature and findings of the studies, the following hypothesis is proposed:

$\boldsymbol{H}_{6}$ : Increasing intensity of neuro-stimuli application on marketing mix elements will lead to an increasing level of purchase intentions of consumers. 
Children aged between 7 and 11 years are expected to process a high level of brand information; however, they cannot comprehend how marketing activities impose them a particular product. Thus, subconscious neuro-stimuli are expected to play a significant role in children's preferences. Children are expected to focus on sensorial stimuli rather than product information. Significantly, product-related colours, smell, and aroma associated with product positively affect their product preference and product opinions (Suhonen \& Tengvall, 2009). In line with the existing literature and findings of the studies, the following hypotheses are proposed:

H7: Effective application of neuro-stimuli on marketing mix elements, will have a positive effect on children's brand preference.

$\boldsymbol{H}_{8}$ : Increasing intensity of neuro-stimuli application on marketing mix elements, will lead to an increasing level of brand preference of children consumers.

\section{RESEARCH METHODOLOGY}

\subsection{Research Design}

An experimental research design is implemented with product poster, product package, and smell employed as the manipulated factors. The experimental design was composed of two studies, and two different consumer groups (women and children) were the participants in each study. The first group of participants in the study were selected among mother-women aged between 30 and 45, who have a child aged between 7 and 11, living in Istanbul and decision-makers for food product purchasing for their children. The second group of participants was composed of children aged between 7 and 11 years, who are in the concrete operational stage. Random sampling method was utilised in selecting the participants where 141 women and 143 children participants were involved in the research study. As the study was conducted before 01.01.2020, there was no need to apply for Ethics Committee approval in order to conduct the research.

\subsection{Experimental Study Setup}

For this study and in line with the experimental design, five hypothetical brands were created, and their corresponding posters and packages were designed. Brands 
were designed not to resemble any existing brands in the market, with equivalent product features and similar brand characteristics. Brand names were determined as Chocolita, Chocolino, Chocobond, Chocobite and Chocoberry.

The research product was chosen as a 'milk chocolate with a strawberry filling' that is a product intended for children's consumption. The strawberry filling is intended to provide a unique character to the product that can be reflected in the product packaging with pink colour association, dominant aromatic profile, and fluid character. Each packaging is marked with an organic certificate logo and has high protein content $(21 \%)$ clause. All back-facade information contents were identical and designed equivalent to the other same category products at the market shelf. Among the five brands, Chocolita brand was designed and manufactured in two different packaging designs: one involving neuro-stimuli and other without neuro-stimuli as control product. Factors that are determined to be neuro-stimuli are pink colour associated with strawberry, the fluidity of filling to emphasise mouthfeel, graphics emphasising the combination of chocolate and strawberry to strengthen the expected sensation, smooth angles identified with sweet taste and change in the texture of packaging to differentiate among others.

\subsubsection{Study 1: Effects of Neuro-Stimuli Application on Women Consumers}

The first experimental study aimed to measure brand awareness, brand quality perception and purchase intention of women consumers by the implementation of marketing stimuli applied on ad posters and packaging as the marketing mix elements. 141 participants were divided into 3 groups by random sampling into sub-groups of 42, 46 and 53. Scenarios are constructed for each participant group involving various compositions of neuro-stimuli. In the first scenario, no neuro-stimulus is utilised; all 5 hypothetical brand posters and packages had standardised features and no differentiation among marketing mix elements. This scenario is called as Brand Standard, represented by BrandsTD. The design of posters and packages for the brands is represented in the following Picture 1. 


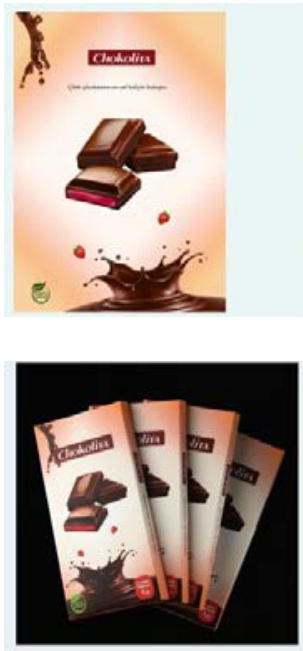

Chocolita
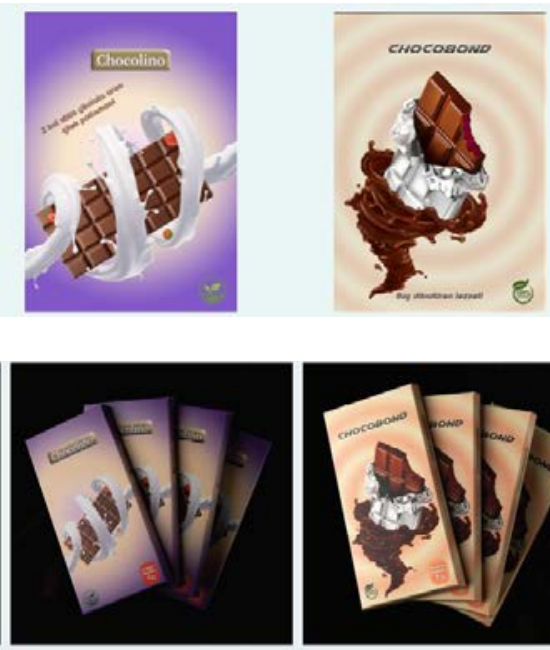

Chocolino

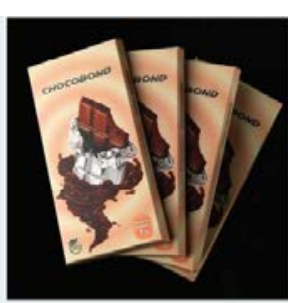

Chocobond
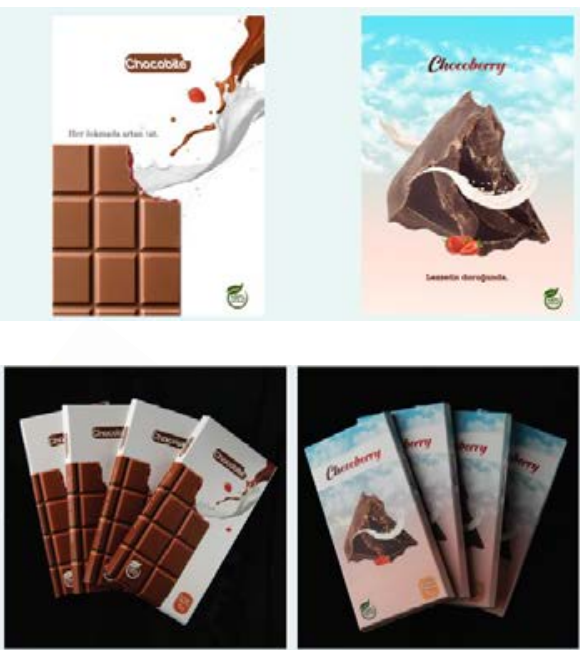

Chocobite

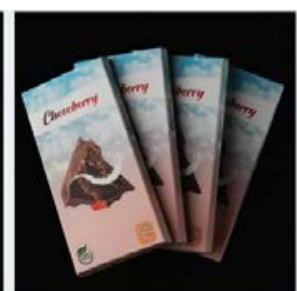

Chocoberry

Picture 1. Brand Standard Scenario Poster and Package Designs

The second scenario involved the use of a combination of neuro-stimuli on Chocolita brand posters to differentiate this brand from others. By use of fluidity in the strawberry filling, pink background associated with strawberry, emphasis on the relationship of strawberry-chocolate by graphics, it is aimed to create the neuro-stimuli

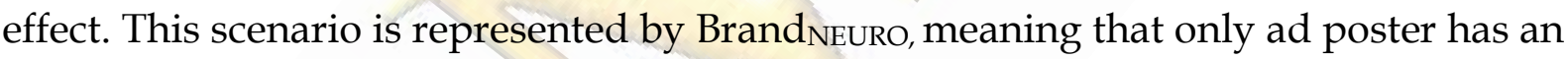
application of neuro-stimuli. The design of posters and packages for the brands is represented in the following Picture 2.

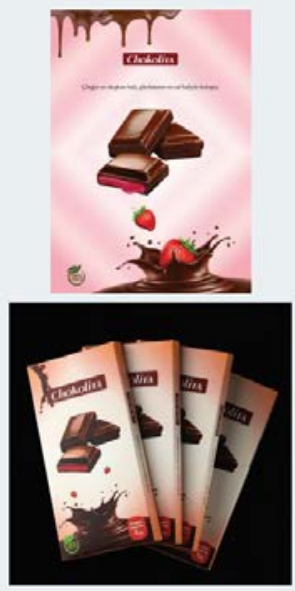

Chocolita

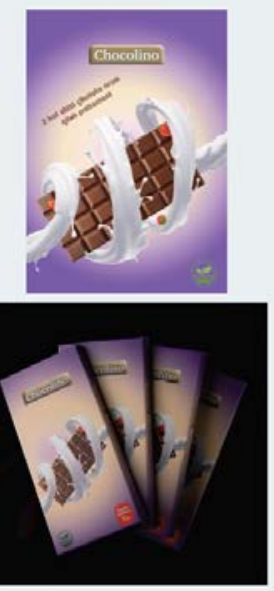

Chocolino

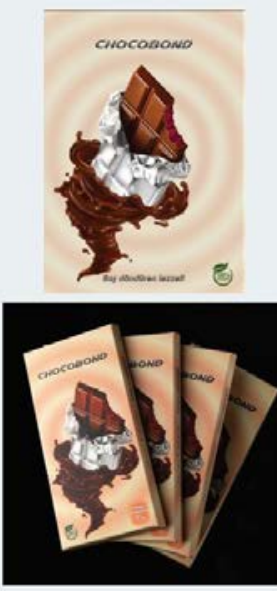

Chocobond

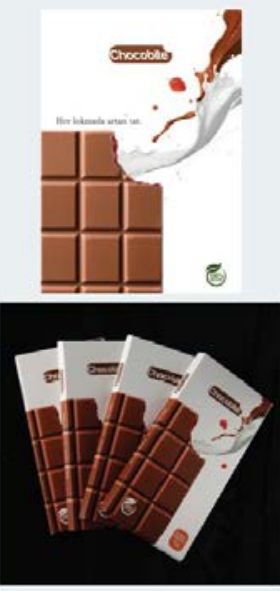

Chocobite

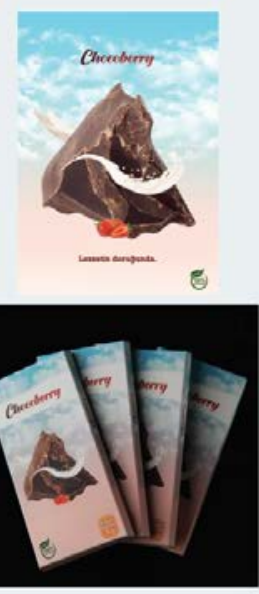

Chocoberry

Picture 2. Brand Neuro Scenario Poster and Package Designs 
In the third scenario, a combination of the same neuro-stimuli is applied to Chocolita brand poster and package to differentiate this brand from others. On both ad poster and package, the fluidity of strawberry filling, pink background, the strawberry-chocolate combination is applied. In addition to these applications, on package oval angles, shiny emboss on texture on strawberry, and fluid filling images are also applied to create the neuro-stimuli effect. This scenario is represented by Brand $_{\mathrm{NEURO}^{+}}$. The design of posters and packages for the brands is represented in the following Picture 3.

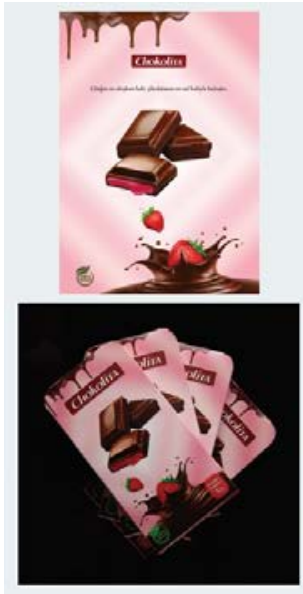

Chocolita

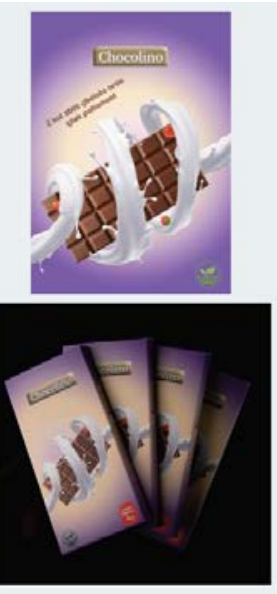

Chocolino

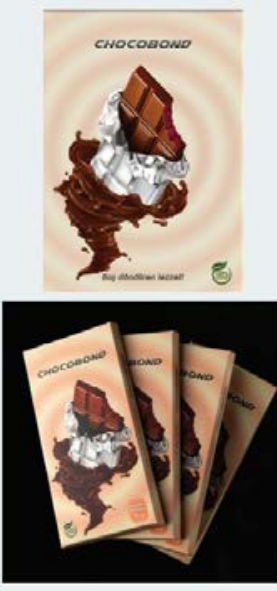

Chocobond

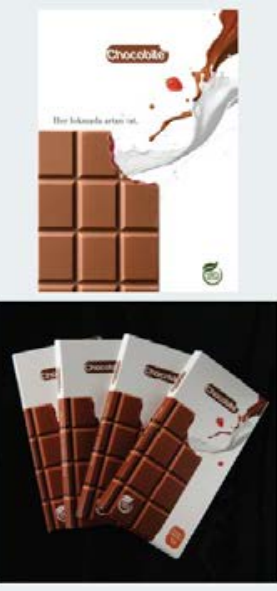

Chocobite

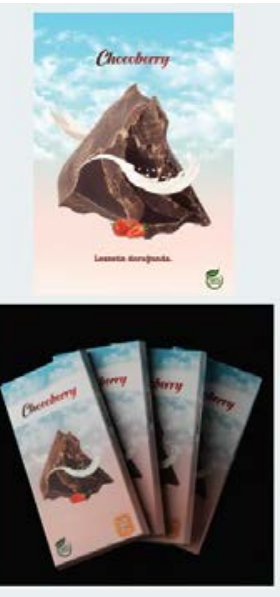

Chocoberry

Picture 3. Brand Neuro Plus Scenario Poster and Package Designs

The experimental design, which is implemented in Study 1, is presented in Table 1.

Table 1. Experimental Design for Women Consumers

\begin{tabular}{|c|c|c|c|c|}
\hline \multirow{2}{*}{$\begin{array}{c}\text { Scenario } \\
\text { No }\end{array}$} & \multirow{2}{*}{$\begin{array}{c}\text { Scenario } \\
\text { Name }\end{array}$} & \multicolumn{2}{|c|}{$\begin{array}{c}\text { Marketing } \\
\text { Elements }\end{array}$} & \multirow{2}{*}{ Manipulation Level } \\
\cline { 3 - 4 } & & Poster & Package & No neuro-stimuli application. \\
\hline 1 & Brand & - & - & Neuro-stimuli on Chocolita poster. \\
\hline 2 & Brand & - & - & NEURO \\
\cline { 1 - 4 } & Brand $_{\text {NEURO }}+$ & + & + & Neuro-stimuli on Chocolita poster \& package \\
\hline
\end{tabular}

The experiment was executed on a laboratory setting in a hall rented and designed as a supermarket store composed of entrance and shopping areas. For each 
scenario applied, the same experimental procedure is applied. In the first part of each scenario applied, participants were invited into the entrance area section and were asked to walk through the area by looking and analysing the chocolate brand posters placed in a row with a distance of 2 meters. Each participant stopped for 10 seconds in front of each ad poster and then proceeded to the next one. Following their ad poster analyses, consumers entered into the shopping area, and they are exposed to a simple supermarket shelf full of chocolate brands employed in the experiment. Participants are asked to approach the shelf and examine the product packages of each brand for 10 seconds. When they finished their examination, they are invited to the outside of the laboratory setting, and they are asked to fill out a questionnaire measuring brand awareness, quality perception and purchase intentions for each brand demonstrated.

\subsubsection{Study 2: Effects of Neuro-Stimuli Application on Child Consumers}

The second experimental study aimed to measure brand choices of child consumers who are aged between 7 and 11 by the use of product packages. Before the experiment, all required permissions are granted from the respective parents of children who are the participants of this study. 143 participants are divided into 3 equivalent groups, each composed of 48,48 and 47 subjects, respectively by employing random sampling technique. Scenarios are constructed for each participant group involving various compositions of neuro-stimuli. In the first scenario, no neurostimulus is utilised; all 5 hypothetical packages had standardised features and no differentiation. This scenario is called as Brand Standard application and represented by BrandsTD. The second scenario involved the application of neuro-stimuli on Chocolita brand packaging to create differentiation. Emphasis on fluidity on graphical design, pink background associated with strawberry, strawberry-chocolate combination, oval-shaped corners, and shiny emboss on texture on filling, and strawberry images are utilised to create the neuro-stimuli effect. This scenario is

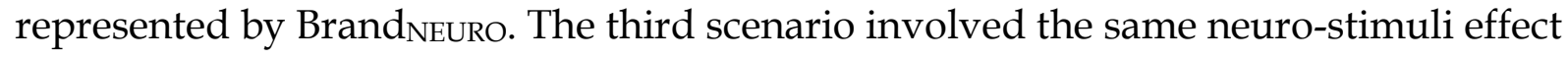
on the same Chocolita brand packaging and supported by strawberry smell by use of artificial edible strawberry flavour to enhance neuro-stimuli by adding another sense. This scenario is represented by Brand NEURO $^{+}$. The experimental design, which is implemented in Study 2 is presented in Table 2. 
Table 2. Experimental Design for Child Consumers

\begin{tabular}{|c|c|c|c|c|}
\hline \multirow{2}{*}{$\begin{array}{c}\text { Scenario } \\
\text { No }\end{array}$} & \multirow{2}{*}{$\begin{array}{c}\text { Scenario } \\
\text { Name }\end{array}$} & \multicolumn{2}{|c|}{$\begin{array}{c}\text { Marketing } \\
\text { Elements }\end{array}$} \\
\cline { 3 - 4 } & & Package & Smell & \multirow{2}{*}{ Manipulation Level } \\
\hline 1 & Brand $_{\mathrm{STD}}$ & - & - & No neuro-stimuli application. \\
\hline 2 & Brand $_{\mathrm{NEURO}}$ & + & - & Neuro-stimuli on Chocolita package. \\
\hline 3 & Brand $_{\mathrm{NEURO}^{+}}$ & + & + & Neuro-stimuli on Chocolita package + smell. \\
\hline
\end{tabular}

In line with the experimental design of Study 1, the experiment in Study 2 was also executed on a laboratory setting in a hall rented and designed as a supermarket store. Under the physical control and supervision of their parents, participants were entered into the shopping area, and they are exposed to a simple supermarket shelf full of chocolate brands employed in the experiment. Participants (child consumers) are directed to the shelf and started to examine the product packages. They are asked to bring the products to their parents starting with the most favourite and till the least favourite one. The most favourite brand was scored as 5, and the least favourite brand (the one which was taken as the last one) was scored as 1.

\subsection{Operationalisation of Variables}

The variables in this study were measured by applying scales employed from the previous studies in corresponding literature with necessary alterations made for this study. Brand awareness scale was borrowed from the study of Zhou, Yang and Hui (2010) who confirmed the reliability and validity of the scale. The seven points bi-polar scale, which is composed of three statements, is translated into the Turkish language and transformed into five points. The perceived quality scale was borrowed from the studies of Sichtmann and Diamantopoulos (2013), who confirmed the reliability of the scale. The seven points scale is composed of three statements to measure quality evaluation of a consumer for products offered by a brand. For this study, the scale items are translated into the Turkish language, reduced to 2 items, and transformed into the five points Likert-Type scale. Finally, consumer purchase intention is measured with a scale developed by Bone and Ellen (1992), who 
confirmed the reliability and validity of the scale. The scale is translated into the Turkish language, and it is transformed into a five-point Likert-Type scale. The statements of brand awareness, perceived quality and purchase intentions are presented in Table 3.

Table 3. Statements of Scales

\begin{tabular}{|c|c|c|}
\hline \multirow{4}{*}{$\begin{array}{c}\text { Brand } \\
\text { Awareness }\end{array}$} & Item No & Statements \\
\hline & 1 & This brand is very unfamiliar / remarkably familiar to me. \\
\hline & 2 & I am not knowledgeable / deeply knowledgeable about this \\
\hline & 3 & I have never seen / I have seen ads about this brand. \\
\hline \multirow{3}{*}{$\begin{array}{c}\text { Perceived } \\
\text { Quality }\end{array}$} & Item No & Statements \\
\hline & 1 & This brand offers high-quality products. \\
\hline & 2 & The quality of this brand's products is far above average. \\
\hline \multirow{4}{*}{$\begin{array}{l}\text { Purchase } \\
\text { Intention }\end{array}$} & Item No & Statements \\
\hline & 1 & It is highly likely that I will purchase this brand. \\
\hline & 2 & In my next purchase, I will prefer this brand. \\
\hline & 3 & Next time I purchase chocolate, I will purchase this brand. \\
\hline
\end{tabular}

Due to the changes made in the original scales in terms of translation and reduction in scale points from seven to five, the internal reliabilities of each scale were tested, and Cronbach Alpha scores of 0,941 for brand awareness, 0,894 for perceived quality and 0,937 for purchase intention scale was reported. Thus, the internal reliabilities of the scales employed was confirmed.

\section{FINDINGS}

\subsection{Normality Checks}

In order to measure the influence of neuro-stimuli applications on consumer behaviour, the scores of each experiment group in each section of the study were compared by employing one-way ANOVA tests. Before conducting one-way ANOVA tests and consequently testing the proposed hypothesis, normality assumptions related to the data were checked in order to be able to process with the required statistical tests. To check whether there is a violation of normality in the data set, a series of numerical as well as graphical methods were employed. 
Numerical tests to confirm the normal distribution of the data set included a ShapiroWilk test as well as the computation of $\mathrm{z}$ scores for each experimental group. The results of the Shapiro-Wilk test or the computation of z scores within the range of \pm 2.58 , as well as graphical analysis of the distributions with the analysis of standard Q-Q plots, confirmed that there was no normality violation in the data set.

\subsection{Study 1: Effects of Neuro-Stimuli Application on Women Consumers}

A series of one-way ANOVA tests were conducted in order to measure the effect of neuro-stimuli applications on women consumers in terms of their brand awareness levels, brand quality perceptions and purchase intentions. The comparison of brand awareness scores of each brand confirmed that Chocolita brand with neuro-stimuli application scored higher $(M=1,67)$ compared to other brands in the experiment. However, the results of the ANOVA test confirmed that this difference is not statistically significant, $F(2,138)=2,138, p=0,075$. Thus, the application of neuro-stimuli on marketing mix elements did not result in a differential effect on the awareness levels of subjects. In light of these results, $\mathrm{H}_{1}$ is not supported. The results of the ANOVA test to evaluate the effect of neuro-stimuli on consumer brand quality perceptions, confirmed that at least one brand has a different perceived quality score compared to other brands in the experiment, $F(2,138)=5,261, p=0,000$. Pairwise comparisons of the scores confirmed that Chocolita brand $(\mathrm{M}=3,23)$, with applications of neuro-stimuli, scored higher compared to Chocobond $(\mathrm{M}=2,72)$ and Chocolino $(\mathrm{M}=2,80)$ brands, and this difference is statistically significant. In light of these results, $\mathrm{H}_{2}$ is supported.

Similarly, purchase intention of women consumers for Chocolita brand that has neuro-stimuli applied on, scored significantly higher $(M=3,31)$ compared to other brands. The results of the ANOVA test confirmed that purchase intention scores for at least two brands are significantly different, F $(2,138)=6,246, p=0,000$. Pairwise comparisons indicated that the purchase intention score of Chocolita brand is significantly higher than scores of Chocoberry $(M=2,79)$, Chocobond $(M=2,63)$ and Chocolino $(M=2,73)$. In light of these results, $\mathrm{H}_{3}$ is also supported. The results of the mean score computation for each brand in terms of brand awareness, perceived quality and purchase intentions are presented in Table 4. 
Table 4. Effect of Neuro-Stimuli on Women Consumer Behaviors

\begin{tabular}{|c|c|c|c|c|c|c|c|}
\hline Brands & Manipulated & \multicolumn{4}{|c|}{ Other Brands } & \multirow{2}{*}{\multicolumn{2}{|c|}{$\begin{array}{l}\text { ANOVA Test Results } \\
\text { Hypothesis Testing }\end{array}$}} \\
\hline & & Chocoberry & Chocobite & Chocobond & Chocolino & & \\
\hline Awareness & 1.67 & 1.40 & 1.52 & 1.41 & 1.48 & $\begin{array}{c}\mathrm{F}(2,138)=2.138 \\
, \mathrm{p}=.075\end{array}$ & $\begin{array}{c}\mathrm{H} 1 \\
\text { Rejected }\end{array}$ \\
\hline $\begin{array}{c}\text { Perceived } \\
\text { Quality }\end{array}$ & 3.23 & 2.96 & 2.98 & 2.72 & 2.80 & $\begin{array}{c}\mathrm{F}(2,138)=5.261 \\
, \mathrm{p}=.000\end{array}$ & $\begin{array}{c}\mathrm{H} 2 \\
\text { Accepted }\end{array}$ \\
\hline $\begin{array}{l}\text { Purchase } \\
\text { Intention }\end{array}$ & 3.31 & 2.79 & 2.90 & 2.63 & & $\begin{array}{c}F(2,138)=6.246 \\
, p=.000\end{array}$ & $\begin{array}{c}\text { H3 } \\
\text { Accepted }\end{array}$ \\
\hline
\end{tabular}

In addition to the brand-based comparisons of brand awareness, perceived quality and purchase intention scores, a series of one-way ANOVA tests were also conducted in order to measure the effect of increasing intensities of neuro-stimuli on the same subject group. In order to realise this target, average scores of brand awareness, perceived quality, and purchase intentions of three experimental groups were compared. First, the average brand awareness scores of BrandSTD, Brand NEURO and Brand $_{\mathrm{NEURO}^{+}}$experiment groups were compared, and the results are confirmed that Brand $_{\text {NEURO}^{+}}(\mathrm{M}=1.80)$ scored higher than BrandsTD $(\mathrm{M}=1.53)$ and Brand ${ }_{\mathrm{NEURO}}$ $(\mathrm{M}=1.51)$. However, this difference was not statistically significant, $\mathrm{F}(2,138)=1.768$, $\mathrm{p}=.175$ ). Thus, the increasing levels of neuro-stimuli application on marketing mix elements did not result in any differential effect on the awareness levels of subjects. In light of these results, $\mathrm{H}_{4}$ is not supported. Similarly, the average perceived quality scores of BrandsTD, Brand ${ }_{\mathrm{NEURO}}$ and Brand $_{\mathrm{NEURO}^{+}}$experiment groups were compared, and the results are confirmed that $\operatorname{Brand}_{\mathrm{NEURO}^{+}}(\mathrm{M}=3.16)$ and $\operatorname{Brand}_{\mathrm{NEURO}^{+}}(\mathrm{M}=3.28)$ scored higher than BrandsTD $(\mathrm{M}=2.96)$ and Brand $_{\mathrm{NEURO}^{+}}$scored higher than Brand $_{\text {NEURO. }}$ However, this difference was not statistically significant, $F(2,138)=1.418$, $\mathrm{p}=.246$. Thus, the increasing levels of neuro-stimuli application on marketing mix elements did not result in any differential effect on the perceived quality levels of subjects. In light of these results, $\mathrm{H}_{5}$ is also not supported. Finally, purchase intentions of women consumers among three different groups were compared, and results 
confirmed that Brand NEURO $^{+}(M=3.42)$ group scored higher than BrandsTD $(M=2.87)$ and Brand $_{\text {NEURO }}(M=3.19)$ groups. The results of the ANOVA test indicated that at least one group has a different score than the other two groups, $F(2,138)=3.132, p=.047$. Pairwise comparisons confirmed that the purchase intention score of Brand $\mathrm{NEURO}^{+}$ $(M=3.42)$ was statistically significantly different from the score of Brand $\mathrm{STD}(\mathrm{M}=2.87)$. However, the difference between Brand $\mathrm{NEURO}^{+}(\mathrm{M}=3.42)$ and Brand $\mathrm{NEURO}(\mathrm{M}=3.19)$ was not statistically different. In light of these results, $\mathrm{H}_{6}$ is partially supported. The results of the mean score computation for each experimental group in terms of brand awareness, perceived quality and purchase intentions are presented in Table 5.

Table 5. Effect of Intensified Neuro-Stimuli on Women Consumer Behaviors

\begin{tabular}{|c|c|c|c|c|c|}
\hline $\begin{array}{l}\text { Groups } \\
\text { Effects }\end{array}$ & $\begin{array}{c}\text { Brand }_{\text {NEURO }^{+}} \\
\text {(M) }\end{array}$ & $\begin{array}{l}\text { Brand }_{\text {NEURO }} \\
\text { (M) }\end{array}$ & $\begin{array}{c}\text { BrandsTD }_{\text {ST }} \\
\text { (M) }\end{array}$ & \multicolumn{2}{|c|}{$\begin{array}{l}\text { ANOVA Test Results } \\
\text { Hypothesis Testing }\end{array}$} \\
\hline $\begin{array}{c}\text { Brand } \\
\text { Awareness }\end{array}$ & 1.81 & 1.51 & 1.54 & $\begin{array}{c}\mathrm{F}(2,138)=1.768 \\
, \mathrm{p}=.175)\end{array}$ & $\begin{array}{c}\mathrm{H} 4 \\
\text { Rejected }\end{array}$ \\
\hline $\begin{array}{c}\text { Perceived } \\
\text { Quality }\end{array}$ & 3.28 & 3.16 & 2.96 & $\begin{array}{c}F(2,138)=1.418 \\
, p=.246\end{array}$ & $\begin{array}{c}\text { H5 } \\
\text { Rejected }\end{array}$ \\
\hline $\begin{array}{l}\text { Purchase } \\
\text { Intention }\end{array}$ & 3.42 & 3.19 & 2.87 & $\begin{array}{c}F(2,138)=3.132 \\
, p=.047 .\end{array}$ & $\begin{array}{c}\text { H6 } \\
\text { Partially } \\
\text { Accepted }\end{array}$ \\
\hline
\end{tabular}

\subsection{Study 2: Effects of Neuro-Stimuli Application on Child Consumers}

In the second study, a series of one-way ANOVA tests were conducted in order to measure the effect of neuro-stimuli applications on child consumers in terms of their purchase intentions. The comparison of purchase intention scores of each brand confirmed that Chocolita brand with neuro-stimuli application scored higher $(\mathrm{M}=3.32)$ compared to all other brands in the experiment. The results of the ANOVA test confirmed that there is at least one group which has a statistically significant score difference compared to other groups, $\mathrm{F}(4,470)=4.478, \mathrm{p}=.001$. Pairwise comparisons of the scores confirmed that Chocolita brand $(\mathrm{M}=3.33)$, with applications of neurostimuli, scored higher compared to Chocobond $(M=2.62)$ and this difference is statistically significant. Thus, the application of neuro-stimuli on marketing mix elements led to a positive influence on purchase intention levels of subjects. In light of 
these results, $\mathrm{H}_{7}$ is supported. In addition to the brand-based comparisons of purchase intention scores in order to measure the influence of neuro-stimuli applications on consumer behaviour, one-way ANOVA test was also conducted in order to measure the effect of increasing intensities of neuro-stimuli on the same subject group. In order to realise this target, the average scores of the purchase intention of three experimental groups were compared. The results of the scores for the experiment groups BrandsTD, Brand $_{\mathrm{NEURO}}$ and Brand $_{\mathrm{NEURO}^{+}}$confirmed that Brand $\mathrm{NEURO}^{+}(\mathrm{M}=3.57)$ group scored higher purchase intention score compared to BrandsTD $(M=2.54)$ and Brand NEURO $_{(M=3.08)}$ groups. The results of the ANOVA test confirmed that there is at least one group which has a statistically significant score difference compared to other groups, $\mathrm{F}(2,140)=5.495, \mathrm{p}=.005$. Pairwise comparisons of the scores confirmed that the difference between the scores of Brand NEURO $^{+}$and BrandsTD groups was statistically significant.

On the other hand, there was no statistically significant difference between the

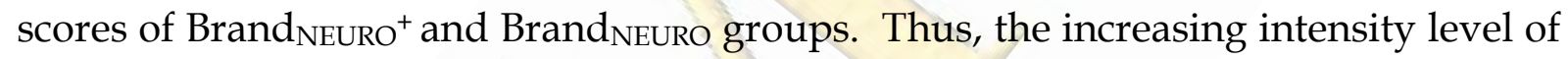
neuro-stimuli on marketing mix elements led to the increasing levels of purchase intention after a minimum level of intensity threshold. In light of these results, $\mathrm{H}_{8}$ is partially supported. The results of the mean score computation in terms of purchase intentions for each brand as well as the experiment group are presented in Table 6.

Table 6. Effect of Neuro-Stimuli on Child Consumer Behaviors

\begin{tabular}{|c|c|c|c|c|c|c|c|}
\hline Brands & Manipulate & & \multicolumn{3}{|c|}{ Other Brands } & \multirow{2}{*}{\multicolumn{2}{|c|}{$\begin{array}{l}\text { ANOVA Test Results } \\
\text { Hypothesis Testing }\end{array}$}} \\
\hline Effects & $\begin{array}{l}\text { Chocolita } \\
\text { (M) }\end{array}$ & $\begin{array}{c}\text { Chocoberry } \\
\text { (M) }\end{array}$ & $\begin{array}{c}\text { Chocobite } \\
\text { (M) }\end{array}$ & $\begin{array}{l}\text { Chocobond } \\
\text { (M) }\end{array}$ & $\begin{array}{c}\text { Chocolino } \\
\text { (M) }\end{array}$ & & \\
\hline $\begin{array}{l}\text { Purchase } \\
\text { Intention }\end{array}$ & 3.33 & 2.75 & 3.17 & 2.62 & 3.16 & $\begin{array}{c}\mathrm{F}(4,470)=4.478 \\
, \mathrm{p}=.001\end{array}$ & $\begin{array}{c}\text { H7 } \\
\text { Accepted }\end{array}$ \\
\hline $\begin{array}{l}\text { Groups } \\
\text { Effects }\end{array}$ & $\begin{array}{r}\text { Brand }_{\mathrm{NEU}} \\
(\mathrm{M})\end{array}$ & & $\begin{array}{c}\text { Brand }_{\text {NEURO }} \\
\text { (M) }\end{array}$ & & $\begin{array}{l}\text { rand } \\
\text { (M) }\end{array}$ & $\begin{array}{l}\text { ANOVA Te } \\
\text { Hypothesi }\end{array}$ & $\begin{array}{l}\text { Results } \\
\text { Testing }\end{array}$ \\
\hline $\begin{array}{l}\text { Purchase } \\
\text { Intention }\end{array}$ & 3.57 & & 3.08 & & 2.54 & $\begin{array}{c}F(2,140)=5.495 \\
, p=.005\end{array}$ & $\begin{array}{c}\text { H8 } \\
\text { Partially } \\
\text { Accepted }\end{array}$ \\
\hline
\end{tabular}




\section{DISCUSSION AND IMPLICATIONS}

The objective of this research study was to measure the effect of neuro-stimuli applications on marketing mix elements in the context of two inter-connected consumer groups, mother-women, and children. Children are initiators in buying processes. Mothers are deciders and mostly buyer as well; hence a purchase decision for a product is determined by the coherence of results of the two study groups. The findings of this study indicated that the application of neuro-stimuli significantly influence the perceived quality and purchase intention of women consumers, but not sufficient to create a significant difference in terms of brand awareness. As the neurostimuli targeting subconscious was found to be positively useful on perceived quality and purchase intentions of women consumers, research findings showed that the use of neuro-stimuli on both ad poster and packaging as marketing tools have a positive effect on perceived quality. However, without packaging application, the results are insignificant. Hence, for integrated marketing efforts, marketers need to make sure that packaging has the same design and message with other marketing mix elements. Research findings are in line with the existing literature reporting the significant cognitive, perceptual, and behavioural effects of neuro-stimuli (Yin et al. 2017; Giray \& Girişken, 2013; Spence \& Ngo, 2012). Specifically, when there is an association of oval shapes with sweet tastes, the marketing mix element becomes more significant. Thus, round finish on two corners of the packaging increased the perceived quality compared to other products and differentiated the product. Moreover, the emphasis on the fluid strawberry filling by graphics and embossed texture increased consumer expectation and outperformed the product, among others, also resulting in the increasing purchase intention. Although the application of neuro-stimuli on posters as well as packages did not result into a significant difference on brand awareness levels, it is strongly believed that neuro-stimuli can be supported by increasing touchpoints between the product and consumer to expose the consumer to the product for longer, which eventually will lead to increasing levels of awareness.

Contemporary food sector requires the integration of emotional marketing and employment of five senses into the product experience. This study partially tested the importance of the integration mentioned above since packaged retail food products 
are purchased without tasting. Not the product itself but the marketing tools associated with product encourage consumers to get into action by activating more regions in the brain. Research results support the assumption that sensorial features are vital for purchase intention of consistent and determined child consumers. In line with the existing literature, the addition of olfactory sense to a product differentiated one product from others and resulted in positive effects on consumer behaviour (Gürdin, 2019; Suhonen \& Tengwall, 2009). The first impression is observed to be critical for the child consumer purchasing process, and this is a more critical factor compared to women consumers. Thus, it can be concluded that sensory details are vital when child consumers are targeted. When child consumers are exposed to a specific smell, their purchase intentions are shaped according to their previous experiences.

As a result, this study contributes to the marketing literature with academic as well as managerial implications generated based on the findings which confirm the significant effect of the neuro-stimuli application on consumer behaviour.

\section{LIMITATIONS AND SUGGESTIONS FOR FUTURE RESEARCH}

This study may have several limitations, including the generalizability of the findings and the psychological effect of experimental design on the participants, which may eventually lead to discriminatory behaviour. First of all, as it is the case in many experimental designs, this study was conducted on a laboratory setting converted into a supermarket store, which was not a real-life environment. Thus, the behavior of participants may be affected since they are not fully involved in a grocery shopping experience. Moreover, the Hawthorne effect may also be an issue since participants were aware that they were observed by the researcher (Kocakaya, 2012). The participants were selected among the citizens of Istanbul, which may not be the representative of the whole country, limiting the generalizability of the study.

This study and its respective findings constitute a foundation for further academic studies on the effect of the neuro-stimuli application on consumer behaviour. It is highly recommended to conduct further studies on different product 
categories, and consumer groups in order to shed light into the unexplored areas of this subject and will contribute to the generalizability of the study findings. 


\section{REFERENCES}

Ampuero, O. and Vila, N. (2006). Consumer Perception of Product Packaging. Journal of Consumer Marketing, 23(2): 100-112. https:/ / doi.org/10.1108/07363760610655032

Anselmsson, J., Johansson, U., and Persson, N. (2007). Understanding price premium for grocery products: a conceptual model of customer-based brand equity. The Journal of Product and Brand Management, 16(6): 401-414. https:// doi.org/ 10.1108/10610420710823762

Auvray, M., and Spence, C. (2008). The Multisensory Perception of Flavor. Consciousness and Cognition, 17(3): 1016-1031. . https:/ / doi.org/10.1016/j.concog.2007.06.005

Bone, P. F. and Ellen, P. S. (1992). The Generation and Consequences of Communication-Evoked Imagery. Journal of Consumer Research, 19 (June): 93-104. . https://doi.org/10.1086/209289

Bozoklu, Ç.P., and Alkibay, S., (2014). Nöropazarlama Kapsamında Tv Reklamlarına Yönelik Duygulanım Tepkilerinin Değerlendirilmesi: Yüz Kasları Analizi İle Anket Yönteminin Karşılaştırılması. Gaziantep University School of Economics Administrative and Social Sciences, 19. National Marketing Congress, 18-22 Haziran 2014 Gaziantep: 143-150.

Calvert, G., Brammer, M. (2012). Predicting Consumer Behavior Using Novel Mind-Reading Approaches, IEEE pulse,3: 38-41. . https:/ / doi.org/10.1109/MPUL.2012.2189167

Ceylan, İ.G., and Ceylan, H.B., (2015). Ambalaj Tasarımında Bilinçaltı Mesaj Öğelerinin ve Nöropazarlama Yaklaşımının Kullanımlarının Karşılaştırılması. International Periodical for the Languages, Literature and History of Turkish or Turkic, 10(2): 123-142.

Chung, J.E., Yu, J.P., and Pysarchik, D.T. (2006). Cue utilisation to assess food product quality: a comparison of consumers and retailers in India. The International Review of Retail, Distribution and Consumer Research, 16(2): 199-214. https://doi.org/10.1080/09593960600572233

Cosmi, Scaglioni, S., and Agostoni, C. (2017). Early Taste Experiences and Later Food Choices. Nutrients, 9(107): 1-9. https://doi.org/10.3390/nu9020107

Dalenberg, J.R., Weitkamp, L., Renken R.J., Nanetti, L., Ter Horst G.J. (2017). Flavor pleasantness processing in the ventral emotion network. PLoS ONE, 12(2), https://doi.org/e0170310.

Dooley, R. (2012). Brainfluence: 100 ways to persuade and convince consumers with neuromarketing. John Wiley, Hoboken: NJ.

Durmaz, Y., Bahar, R., and Kurtlar, M. (2011). Kişisel Faktörlerin Tüketici Satın Alma Davranışlarına Etkisi Üzerine Bir Araştırma. Akademik Yaklaşımlar Dergisi, 2(1): 114-133.

Fitzsimons, G.J., Hutchinson, J.W., and Williams, P. (2002). Non-Conscious Influences on Consumer Choice. Marketing Letters, 13(3): 269-279.

Friese, M., Wänke, M., and Plessner, H. (2006). Implicit consumer preferences and their influence on product choice. Psychology \& Marketing, 23(9): 727-740.

Giray, C., Girişken, Y. (2013). Gözün Bilinç Seviyesinde Duyumsamadığı Uyaranları Beyin Algılaması Mümkün müdür? Nöropazarlama Yöntemi ile Ölçümleme Üzerine Deneysel Bir Tasarım, Kafkas Üniversitesi İktisadi ve İdari Bilimler Fakültesi, 18. Ulusal Pazarlama Kongresi, 19-22 Haziran 2013, Kars/Sarıkamış, 608-618.

Gürdin,B. (2019). Kokunun Tüketici Satın Alma Davranışı Üzerindeki Etkisi. Journal of Business ResearchTurk, 11(3): 2160-2175.

Hansen, T. (2005). Understanding consumer: Perception of food quality: the cases of shrimps and cheese. British Food Journal, 107(7): 500-525. 
Howard, J. A. and Sheth, J. (1969). The Theory of Buyer Behavior. Journal of the American Statistical Association. January(1969): 467-487.

Jugger, S. (2008). The power of packaging. Admap Magazine.

Kocakaya, S. (2012). Deneysel Çalışmalar Ne Kadar Güvenilir? Ë̆gitim ve Öğretim Araştırmaları Dergisi, 1(2): $225-231$.

Kotler, P., Kartajaya, H., and Setiawan, I. (2017). Pazarlama 4.0 Gelenekselden Dijitale Geçiş (N. Özata, Çevirisi). Optimist Yayınevi: İstanbul.

Kömürcüoğlu, F., (2016), Pazarlama İletişim Sürecinin Etkinliğini Arttırmada Nöropazarlama: Bir Alan Araştırması Muğla Sıtkı Koçman Institute of Social Sciences Unpublished Master's Degree Thesis, Muğla-TURKEY.

Kringelbach, M. L., and Berridge, K. C. (2010). The functional neuroanatomy of pleasure and happiness. Discovery medicine, 9(49): 579-587.

Kumar, H., and Singh, P. (2015). Neuromarketing: An Emerging Tool of Market Research. International Journal of Engineering and Management Research, 5(6): 530-535.

Lindstrom, M. (2009). Buyology: How Everything We Believe About Why We Buy is Wrong. London, UK: Random House.

Moreira, A, Fortes, N., and Santiago, R. (2017). Influence of sensory stimuli on brand experience, brand equity and purchase intention. Journal of Business Economics and Management, 18(1): 68-83.

Olds, J. and Milner, P. (1954). Positive reinforcement produced by electrical stimulation of septal area and other regions of rat brain. Journal of Comparative and Physiological Psychology, 47(6): 419-427.

Renvoise, P. and Morin, C. (2016). NöroMarketing Müşterinizin Beynindeki Satın Alma Düğmesine Basmak! (Yertutan, Y. Çev.). MediaCat Kitapları: İstanbul.

Rundh, B. (2007). The Multi-Faceted Dimension of Packaging, British Food Journal, 107(9): 670-684.

Schiffman, L. G., and Kanuk, L.L. (1997). Consumer behavior. Upper Saddle River, N.J: Prentice Hall.

Schlossberg, H. (2012). Effective packaging talks to consumers. Journal of Business Strategies, 6(2): 1-10.

Sichtmann, C. and Diamantopoulos, A. (2013). The Impact of Perceived Brand Globalness, Brand Origin Image, And Brand Origin-Extension Fit on Brand Extension Success. Journal of The Academy of Marketing Science, 41 (5): 567-585.

Silayoi, P. and Speece, M. (2004). Packaging and purchase decisions: an exploratory study on the impact of involvement level and time pressure. British Food Journal, 106(8): 607-628.

Singh, P. (2015). Neuromarketing: An Emerging Tool of Market Research. International Journal of Engineering Business Management, 5: 530-535.

Smith, E. and DeCoster, J. (2000). Dual-Process Models in Social and Cognitive Psychology: Conceptual Integration and Links to Underlying Memory Systems. Personality and Social Psychology Review, 4(2): 108131.

Spence, C., and Ngo, M.K. (2012). Assessing the shape symbolism of the taste, flavor, and texture of foods and beverages. Flavour, 1(12): 1-13.

Spence, C. (2016). On the psychological impact of food colour. Flavour, 4(21): 1-16.

Spence, C. (2015). Just how much of what we taste derives from the sense of smell? Flavour, 4(30): 1-10. 
Spence, C. (2015). Eating with our ears: assessing the importance of the sounds on consumption on our perception and enjoyment of multisensory flavour experiences. Flavour, 4(3): 1-14.

Spence, C. (2017). Gastro Physics: The New Science of Eating. Penguin Books: UK.

Spence, C. and Velasco, C. (2018). On the multiple effects of packaging colour on consumer behaviour and product experience in the 'food and beverage' and 'home and personal care' categories. Food Quality and Preference, 68: 226-237.

Stevenson RJ, Prescott J, and Boakes RA. (1999).Confusing tastes and smells: how odours can influence the perception of sweet and sour tastes. Chem Senses, 24(6):627-635.

Suhonen, T. and Tengvall, J. (2009). Branding in the air: A study about the impact of sensory marketing. Unpublished Bachelor's thesis, Department of Business Administration, Jönköping International Business School, Sweden.

Thalhammer, R. R. (2007). Natural product packaging: reflecting a contemporary philosophy. Global Cosmetic Industry, 175(12): 52-55.

Topçu, Y., Işık, B., and Dağdemir, V. (2007). Yeni Ekonomide Gıda Pazarlamasının Değişen Rolü. Atatürk Üniversitesi Ziraat Fakültesi Dergisi, 38(2): 207-214.

Ustaahmetoğlu, E. (2015). Nöropazarlama üzerine bir değerlendirme. Business \& Management Studies: An International Journal, 3(2): 154-168.

Uzunoğlu, M. (2019). Nöro-Uyaranların Tüketici Davranışları Üzerindeki Etkisinin Ölçümü: Gıda Sektörü Üzerine Bir Çalışma. Yüksek Lisans Tezi. İstanbul Okan Üniveristesi, Gastronomi Ana Bilim Dall, Gastronomi Programi.

Vazquez, D., Bruce, M., and Studd, R. (2003). A case study exploring the packaging design management process within a UK food retailer. British Food Journal, 105(9): 602-617.

Venter, K, Van der Merwe, D., De Beer, H., Kempen, E., and Bosman, M. (2011). Consumers' perceptions of food packaging: an exploratory investigation in Potchefstroom South Africa. International Journal of Consumer Studies, 35(3): 273-281.

Wang, E. (2013). The influence of visual packaging design on perceived food product quality, value, and brand preference. International Journal of Retail \& Distribution Management, 41(10): 805-816.

Yin, W., Hewson, L., Linforth, R., Taylor, M., and Fisk, I.D. (2017). Effects of aroma and taste, independently or in combination, on appetite sensation and subsequent food intake. Appetite, $114: 265$ 274.

Yorgancılar, F. N. (2015). Tüketici Davranışı Nörolojisi. Konya: Çizgi Kitapevi.

Yücel, A., and Coşkun, P. (2018). Nöropazarlama Literatür İncelemesi. The Journal of International Social Sciences, 28(2):157-177.

Yücel, N, Yücel, A, Yılmaz, A.S., Cubuk, F., Orhan, E.B., and Şimşek, E.B. (2015). Coffee Tasting Experiment from the Neuromarketing Perspective. The 2015 WEI International Academic Conference Proceedings, 29-35.

Zhou, L., Yang, Z., and Hui, M.K. (2010). Non-Local or Local Brands? A Multi-Level Investigation into Confidence in Brand Origin Identification and Its Strategic Implications. Journal of Academy of Marketing Science, 38 (2): 202-218. 